\title{
(Un)Making smallness: Islands, spatial ascription processes and (im)mobility
}

\author{
Sarah Nimführ \\ Department of Cultural Studies, University of Art and Design, Linz, Austria \\ sarah.nimfuehr@ufg.at (corresponding author)
}

\author{
Laura Otto \\ Institute for Cultural Anthropology and European Ethnology, Goethe-University, \\ Frankfurt, Germany \\ otto@em.uni-frankfurt.de
}

\begin{abstract}
Official categorization systems classify some states, including island-states, as small. Malta, located in the Mediterranean Sea, is one of six European microstates and the European Union's smallest member state. Smallness, however, refers to more than fixed geographic scales. The understanding of smallness developed in this article, in contrast, moves beyond geographic features and argues instead that smallness is related to perceptions, experiences, and ascriptions. We challenge universal understandings of smallness against the backdrop of ethnographic research carried out in Malta (2013-2018) by exploring how island-related smallness is produced and used situationally in the context of (im)mobility. By focusing on narratives of smallness by various actors with whom we engaged during fieldwork, we demonstrate how smallness, islandness, and (im)mobilizing policies intersect at the EU's external border. In addition, and in order to contribute to decolonial perspectives within Island Studies, we reflect on our role in (un)making smallness. We discuss our understandings of smallness against the backdrop of our empirical material and scholarly debates, and, in so doing, avoid the reproduction of universal understandings. In this vein, we argue for the deconstruction of simplified interpretations of smallness and claim that smallness must be viewed as a relational concept.
\end{abstract}

Keywords: smallness, representation, relationality, islanding, mobility

http://doi.org/10.24043/isj.173 • Received February 2021, accepted August 2021

\section{Introduction}

It is the summer of 2015, Hassan, a young asylum seeker from Somalia who arrived in Malta in 2013 and was thereafter classified as an unaccompanied minor (UAM), stated that he had begun enjoying the Mediterranean island-state: after a few years in Europe, he said that he liked the beaches, the warm weather, and the Maltese landscape. Yet, he also reflected that he felt imprisoned to a certain extent as he was not allowed to travel to other countries due to his ascribed underage. As a result, he found that Malta was at times too small. It is the summer of 2018. Tom and Michelle, a tourist couple from Germany, also attested the Maltese 
island-state great weather, nice beaches, good food, and fun things to do. What they shared with Hassan was the impression that the archipelago does have beautiful things to offer. Further, they said that the island-state's smallness made it possible for them to do many different things during a short period of time - however, they could not imagine living there, as they found Malta too crowded, too loud, and too small. But that was not a problem, as at the end of their vacation they could easily get on a plane and fly back to Germany, while Hassan had to stay.

What these anecdotes reveal is that smallness, islandness, and (im)mobilizing policies intersect at the European Union's (EU) external border in Malta. This article takes seriously different and contradictory perspectives and perceptions of smallness which stem from ethnographic research carried out in Malta between 2013-2018. The Maltese case is relevant and interesting for a discussion of smallness for various reasons: in public discourse, smallness was mainly used and repeatedly emphasized as a defensive argument to keep refugees at bay. Furthermore, Malta was represented as being overpopulated, which required Maltese society to be protected from unwanted newcomers. While smallness was often naturalized, viewed as a geographical feature and therefore not often viewed as a social product, we learned during fieldwork that attributions of smallness, periphery, and center were ascriptions that were negotiated subjectively. In addition, they were and are experienced in various ways. To emphasize this construction linguistically, we put smallness in italics. As researchers, we do not stand outside of discourses and productions of smallness, and also have to question our own attributions of 'periphery', 'smallness', and 'reduction of complexity'. With our contribution, we neither wish to reproduce political arguments used against refugees unquestioningly (see, e.g., Triandafyllidou, 2014), nor are we interested in perpetuating naturalized understandings of smallness. Consequently, our contribution is an attempt to counter these dominant narratives with a differentiated and differentiating perspective on smallness. We illustrate empirically which meanings and makings of smallness occur in the context of forced migration in Malta. Against this background, we ask: How is island-related smallness produced and situationally used in the context of (im)mobility? How do smallness, islandness, and (im)mobilizing policies intersect at the EU's external border on the Maltese island-state?

To address this lacuna, we embed our research in both Island Studies literature especially within the decolonial island studies project (Nadarajah \& Grydehøj, 2016, p. 441) and the relational research strand (Pugh, 2016, 2018; Sheller, 2009; Stratford et al., 2011) and, more broadly, within relational understandings of space. Space, here, is not geographically given and unchangeable per se, but culturally constituted and the result of social practices. We distance ourselves from conceptualizations of space as "closed containers" (Schroeder, 2003) with clear and closed borders. More actor-centered perspectives and practical-theoretical understandings (Hörning \& Reuter, 2004) significantly contribute to a dynamization of spatial concepts, and these performative understandings replace and complement purely territorial concepts of space (cf. Eckert et al., 2020, p. 193; Gottschalk et al., 2018, p. 8). According to this understanding, actors are simultaneously involved in local and global dynamics, as geographer Doreen Massey (1994, p. 7) argues: "what gives a place its specificity is $[\ldots]$ the fact that it is constructed out of a particular constellation of social relations, meeting and weaving together at a particular locus."

The particular locus we look at in this article is, as mentioned above, the Maltese islandstate. Taking seriously literature from within Island Studies is all the more helpful and relevant 
here. Engaging with Cyprian Broodbank's (2000) 'islandscape' and Epeli Hau'ofa's (1994) 'Our sea of islands' helped us to deconstruct our own preconceptions about geographical 'disconnectedness', 'smallness', and especially small(er) islands and their relation to the supposed 'larger world' (see also Lowenthal, 1992, p. 19; Nimführ \& Otto, 2020). Both concepts understand islands as connected to other islands, the mainland, and the sea. The sea has a special significance, as it is not perceived as isolating but as a constitutive and connecting part of islands. Even if these concepts acknowledge the islands' physical existence (Broodbank, 2000 , p. 33), they are understood "beyond their physical boundaries" (Vogiatzakis et al., 2017 , p. 2) leading to the idea of a relative smallness (Hau'ofa, 1994, p. 152). According to Hau'ofa (1994, p. 152), "[s]mallness is a state of mind," which entails that outsiders often conceive of islands as separated and confined as well as defined through their (national) borders, which often arose from colonial and decolonial dynamics thereby overlooking connectivity, heterogeneity, and complexity. In fact, it is a powerful state of mind that neglects the relationalities and disregards the diversity of islands by "lumping small islands together into one category" (Walshe \& Stancioff, 2018, p. 14). Recent publications from within Island Studies have shown that insular smallness cannot be considered a natural given, but is co-produced by various actors, and that islands "are subject to their own centerperiphery tensions" (Grydehøj et al., 2021, p. 4). Malta's (post)colonial past and present are worth mentioning here, as they impact these tensions. Of all the Western Mediterranean countries which receive refugees, Malta is the only country that was colonized and ruled by various foreign powers and now has to deal with refugees who have left a postcolonial African continent (Baldacchino, 2010). Malta's own history of colonization is significant because "places never really shake off their past" (Royle, 2010, p. 203). According to Jane M. Jacobs (1996, cited in Royle, 2010, p. 204), fundamental components of both colonial and postcolonial formations of the present are the materiality of a place, its imaginative spatiality, and its cultural politics of territory.

In this article, we contribute to this literature by asking how island-related smallness is produced and situationally used in the context of (im)mobility, and how smallness, islandness, and (im)mobilizing policies intersect at the EU's external border on the Maltese island-state. We add a perspective on smallness at the intersection of geographical features, policies, and (im)mobility, and address these questions with our ethnographic material. As is common in the ethnographic research tradition, we let the material 'speak' (Dracklé, 2015) and thus focus on the everyday level of the production of smallness, which has been dealt with too little so far. Situating smallness ethnographically allows us to develop an empirically saturated understanding thereof in the context of (im)mobility. By doing so, we demonstrate that perceptions and effects of island dimensions are context- and actor-dependent.

\section{Islands and smallness: Literature review and theoretical perspective}

In both academic and public discourse, islands and smallness are often mentioned contemporaneously. When islands are considered as a "distinct type of colonised geography" (Grydehøj et al., 2021, p. 4), ascriptions of smallness and a disregard of transnational mobility practices often occur. In this context, insular smallness correlates, on the one hand, with Westernized paradisiacal phantasms as pointed out by island scholars Godfrey Baldacchino 
(2008) and Stephen A. Royle (2001) with reference to tourism mobility, and, on the other hand, with spatial confinement, as critically noted by Epeli Hau'ofa (1994) and Tracey Banivanua Mar (2016). Islands, according to geographer Russell King (2009, p. 55), evoke certain ascriptions of isolation and condensation, especially among researchers, and are predestined for the continuation of a colonial view. In reference to the term 'othering', Baldacchino (2007, p. 2) describes this phenomenon as "islanding." Island studies' scholars have criticized homogenizing and uncritical ascriptions of islands as being 'small' and therefore 'simple' or merely being a representation of the big world within a small place (Baldacchino, 2018; Grydehøj, 2017; Lowenthal, 1992). Baldacchino (2005) posits that people have strong ideas about what islands and who islanders are, which leads them to overlook their diversity and heterogeneity. He voices a critique of denying islands' duality; instead, he points out that islands are embedded within local and global dynamics (Baldacchino, 2005, p. 248). In a similar stance, Adam Grydehøj (2017, p. 3) issues a warning against the misuse of island spatiality "to produce idealized visions of islands." These debates are embedded in discourse about the history of colonization of islands, decolonization processes, and persisting neocolonial dependencies. Islands have experienced a particularly intense history of foreign domination. James Lewis (2009, p. 5) reminds us that "small islands were for the taking, islanders were overwhelmed and their lands appropriated, occupied, colonized and governed for the purposes of greater powers." It is unsurprising, then, that Island Studies scholars argue against viewing a particular island as isolated and opt instead to study it merely on "its own terms" (Grydehøj, 2017, p. 8). This also applies to the concept of smallness, which has the potential to perpetuate colonial subordination and thus should not be transferred without scrutiny. Rather, Yaso Nadarajah (2007, p. 129) pushes the debate forward by arguing for a "reflexive encounter with ontological and epistemological coordinates."

\section{Conceptual definitions: Islands between materiality and metaphor}

Despite these arguments and warnings, "spatial laboratory" approaches (for a critical view, see King, 2009, p. 57; Lowenthal, 1992, p. 18) which designate islands as "places of condensation" (e.g., Bernardie-Tahir \& Schmoll, 2014, p. 94) can still be found in human geography, ethnology as well as cultural and social anthropology. Recent studies even attest that "(i)slands may have a tremendous opportunity to serve as laboratories for studying the SARS-Cov-2 and the spread of COVID-19 disease" (Telesford, 2021, p. 321), thereby recalling scientific experimentation on islands which date back to the early 1500 s when islands were viewed as "ideal laboratories" (Royle \& Brinklow, 2018, p. 16). These approaches contribute to the reduction of islands' smallness and reproducing powerful representations of them, which result in the figure of the — especially small — island still being declared a symbol of powerlessness in relation to political processes in contemporary Western culture and scholarship (Chandler \& Pugh, 2020). Island Studies generally views these forms of representation critically. Baldacchino (2004, p. 278) remarks that the reproduction of islands as manageable, uncomplex social microcosms or laboratories entails the problem of representing islanders as "simple, sensuous, savage natives or passive respondents." Curious scientists from the West collect material about them in "jet set mode" and construct "island truth" (Baldacchino, 2004, p. 278). In other words, islands are not microcosms that represent in "small" what can be found elsewhere in "big" (Baldacchino, 2014, p. 58). 
There are no scientific dividing lines or thresholds defining the size of a small island, although various organizations have proposed definitions, such as the UN in its definition of Small Island Development States (SIDS) or the intergovernmental organization Alliance of Small Island States (AOSIS). According to the UNESCO definition of small islands, "(i)slands with surface areas under 10,000 square kilometers and fewer than 500,000 inhabitants should be considered small” (Hess, 1986). Baldacchino (2018, p. xxvi) critically notes that even the land area, resident population, and economic importance of islands and/or small (island) states is always ambiguous:

Is Greenland, the world's largest island at 2 million $\mathrm{km}^{2}$ but with a population of less than 60,000 , small or large? How to come to terms with places like Kiribati [...], a Pacific archipelago of hardly 100,000 residents but steward over an oceanic space larger than the land area of Europe? It may be a 'small island state' in the eyes of the UN, but is it not also a 'large ocean state' (Cook 2016)?

An understanding of space that considers both the materiality and the imaginations of those who create and "do" space — and "do" size (Eckert et al., 2020, p. 193) — is important to conceive of smallness as produced and acted out (Löw, 2001; Massey, 1994). Against the backdrop of social constructivist spatial theories, different actors perceive, use and (re)produce smallness differently. According to cultural and social anthropologists Andre Gingrich and Ulf Hannerz (2017, p. 6), smallness is relative and must be understood and examined from the actors' perspective. To describe a place as small, there must be a relevant reference place 'elsewhere'. Both the 'here' and 'there' are omnipresent in the formation of local imaginaries and can be discursively activated at any time. Smallness thus relates to how islanders feel about the island they inhabit, especially "vis-à-vis their continental neighbors" (Lowenthal, 1992, p. 19). In this vein, an island is an actual geographical place, but also a social and constructed space created through the 'human imprint' (Broodbank, 2000). The relevance of a certain spatial scale is therefore not a priori given, but is created through the actions of actors on the ground (Belina, 2008, p. 112). Some scholars have already studied the differentiation of the meaning and utilization of smallness in the context of Island Studies, arguing for a contextsensitive approach (Anckar, 2006, p. 43). Baldacchino (2000, in Anckar, 2006, p. 43) demonstrates that smallness in combination with 'islandness' enables rapid political action. Cetta Mainwaring (2019, p. 127) argues that the Maltese government made strategic use of the island-state's smallness to successfully gain power within higher echelons of EU bureaucracy. Recent research by political scientists Wouter Veenendaal and Jack Corbett (2020) suggests that small states in the Caribbean and the Pacific tend towards increased clientelism. With regard to climate change, Rory Walshe and Charlotte Eloise Stancioff (2018) highlight that small islands and their residents have complex relationships with climate change, thereby challenging oversimplification and ignorance from the Global North. In this vein, and contrary to the idea that small land areas and populations create vulnerability (Kelman, 2018, p. 157), Ilan Kelman (2021, p. 118) calls for "us[ing] islandness to create resilience [...] against assumptions that characteristics such as smallness and isolation are the antithesis of resilience." These studies refrain from using smallness as an explanatory category for all dynamics on islands but differentiate and specify what smallness means in specific 
contexts and how it is made use of. Thus, smallness is understood here as situated and contextspecific. Developing a critical perspective on smallness is particularly relevant when this category is used in political arguments. As 'threats' from the outside are understood as particularly worrying in small states (Gingrich \& Hannerz, 2017, p. 31), we think of smallness not only in terms of its geographical and demographic materialization, but also as a political and social category. Geographer Bernd Belina (2008, p. 118) stresses that producing spatial scales can also be a (politically) contested process. This assumption is based on constructivist and relational concepts of space: Henri Lefebvre (1998) states that spatial arrangements and social relations are interrelated. Thus, spaces are not neutral objects. Instead, they are negotiated in an ongoing process; their meanings are negotiable and changeable. The assumption, here, is that not all actors involved in the production of space are equipped with the same degree of power to do so. Space productions are thus characterized by unequal power distributions and hierarchies (see Belina, 2008; Massey, 1993) - dynamics in which researchers are also entangled.

\section{Methods and positionality: Doing research on small(er) islands}

This article is based on ethnographic fieldwork carried out between 2013 and 2018 in Malta. Sarah Nimführ focused on refugees whose asylum applications were rejected and were nondeportable (2015-2018); Laura Otto's research (2013-2018) focused on the situation for young refugees categorized as UAMs. Both groups were essentially precluded from leaving Malta in a regulated fashion and they were also not granted refugee protection. In this article, we refer to our research partners as 'refugees' to refer to their experiences and to highlight the situation of involuntariness in which they found themselves.

Following a polyphone approach, we not only interacted with refugees from various African countries, but we also dealt with non-refugee actors, such as volunteers, and with institutional actors, e.g., bureaucrats, NGO employees, and politicians. Laura Otto was in contact with 48 refugees classified as UAMs and 17 young refugees who were not categorized as such; she also interviewed 12 institutional actors. Sarah Nimführ interacted with 22 refugees classified as rejected asylum-seekers, interviewed 27 officials, and held informal talks. Additionally, both conducted participant observation in refugee housing centers and refugees' flats, in ministries and NGO's offices, as well as in public settings. In the course of a joint revisit in 2018, we had further talks with three institutional actors. We complemented our material with policy documents, newspaper articles, and NGO reports. All research partners were informed of our research goals and projects and gave their informed consent either verbally or in written forms. Ethnographic research always requires a high degree of sensitivity; this is all the more true for research on forced migration and poses particular challenges for researchers in geographically small areas. Smallness is therefore not only an emic concept of the actors from the field, but also concerns researchers.

Conducting research in a geographically relatively small area where many actors know one another requires researchers to consider how to pseudonymize one's material to protect the research partners as well as possible without rendering their function unrecognizable (in more detail see Nimführ et al., 2020, p. 163). Therefore, we used pseudonyms for persons we interviewed as well as for organizations and relevant places - except for the capital, 
Valletta. This being said, pseudonymization proved difficult, as the island-state's size makes certain locations in Malta unique.

Smallness and complexity

Carrying out research in an area characterized by intense proximity of diverse actors confronts researchers with challenges and numerous questions. It should be noted that geographical smallness does not imply less complexity during research. Malta is by no means a closed microcosm in which larger phenomena - such as tourism or forced migration - are depicted in a small, uncomplex version (Baldacchino, 2014, p. 58). Moreover, geographical smallness does not mean that research can be conducted more quickly or more easily than in larger places. Particularly due to a 'hype' in forced migration research, many researchers from various disciplines have visited islands of arrival such as Malta, Lesbos, and Lampedusa often only for a short stopover (e.g., Bernardie-Tahir \& Schmoll, 2014; Franck, 2017; Mannik, 2016). These approaches run the risk of reinforcing the extrapolation of islands as laboratories, as criticized by Baldacchino (2004, 2014), and lead to an (inappropriate) simplification of social phenomena studied on islands. Furthermore, "border spectacles" (De Genova, 2015) on islands also attract numerous researchers for a short period of time, which in turn leads to tendencies of over-exploration. However, if researchers repeatedly return to their research location and engage with the place over a longer, but not necessarily coherent, period of time (Welz, 2013), they can design processual research questions and consider changes, too. To avoid being perceived as a research 'mayfly', it is helpful to demonstrate our lasting interest in local actors, their perspectives, their experiences, and their everyday work. Especially a 'one-and-done attitude' — visiting the research location only once and producing knowledge based on rather casually collected material within a short time period - reinforces the attribution that small places are relatively simple and easy to grasp and relations, contexts, as well as the historicization of the place often remain overlooked. In contrast, however, hasty attributions and reproductions of (our imagined) smallness can be counteracted by means of a recursive research design. Fieldwork divided into several phases made it possible to constantly renegotiate proximity and distance. While away from the physical research site, one can reflect on one's own relationship with the research field.

\section{Co-presence in the context of relative smallness}

In Malta, diverse actors with different interests negotiated forced migration, tourism, trade, administration, and agriculture within a relatively compressed area. This inevitably resulted in their copresence (Gingrich \& Hannerz, 2017), entailing a high chance of encountering each other, which blurred the boundaries between public and private (Gingrich \& Hannerz, 2017 , p. 21). In Valletta and the neighboring city of Sarrija, various NGOs and ministries were located close to one another. At the border of the two cities lay the Local Migrant Administration Organization (LMAO), a local authority of the Ministry of the Interior, which is responsible for refugee accommodations. An interview with the former director of LMAO, Albert Mizzi, made the relationship of (geographical) proximity and (social) distance between refugees and administrators particularly clear. After a joint conversation, Mizzi referred to the port by pointing his hand out of the window. From here, he could watch the Maltese Military Rescue Unit bring refugees ashore. 
In Valletta and Sarrija, LMAO and various NGOs were located close to each other and were relatively central and easy to reach with public transport. The airport, the military area, and the adjacent Savun Barracks detention center, in contrast, were located on the southern part of the island in rural areas with poorer infrastructure. The latter is part of the Maltese 'detention regime', as Ministry of the Interior employee Dom Fenek coined the dynamics in an interview in July 2015. Until the end of 2015, all newly arrived refugees who entered Malta in an irregular manner were detained here. Following detention, the majority moved to Tal Gebel Open Center, which was close to the barracks and the largest open center on the main island. The difference between the open center and the detention center was that residents could leave the former at specific times of the day. Despite its proximity to the airport, the infrastructure was poor, and the bus rarely stopped here, meaning residents faced difficulties in finding a job, having access to NGOs, and even going to grocery stores or pharmacies (Otto et al., 2019).

These two examples mirror larger dynamics in Malta. The participants of our research found themselves in close (geographical) proximity, yet we often perceived distance at the social level. This became apparent, for example, when racist statements were made in public, when derogatory comments about refugee-organized demonstrations were posted on social media platforms and online fora, or when we tried to catch a bus together with research participants who experienced forced migration - drivers of half-full buses did not stop, instead indicating non-verbally that the bus was already full. Physical proximity therefore did not automatically lead to mutual goodwill. Paul Keller from a Maltese NGO shared these observations when we interviewed him in June 2018. He argued that Malta's small size led to tendencies of internal segregation practices, creating an image as if there was no space for newcomers on the island-state: "You always have these demarcations here. This 'us' against the 'others'," he said. While the NGO he worked for tried to establish contact between refugees and Maltese society, he still believed that the line between an imagined 'us' (Maltese society) and 'them' (refugees) was continuously upheld.

\section{Self-reflection on co-produced smallness}

As mentioned at the outset of this article, it is necessary that we - as researchers from the Global North - reflect our position in research to address issues of colonial dominance and Eurocentrism, as Grydehøj et al. (2021, p. 3) also emphasize. To do so, we reflect on our role as researchers in the context of smallness, islandness, and restrictive mobility policies. This article led us to reflect on our last joint visit to Malta back in 2018. We noted in our research diary that we seemed to be able to picture the entire island-state in just a few minutes while the airplane we took cruised over the archipelago during the approach to land at the main island's airport. This reveals that we — at least at times — understood the island-state as small and manageable because of the possibility to see it in its entirety within a few minutes' flight. Obviously, we both looked at Malta as Europeans who were socialized on the mainland and apply a non-insular perspective (Grydehøj, 2018). Thus, at the beginning of our research, our descriptions of Malta's size only took the land mass into account. In so doing, we succumbed to a common and problematic pattern: we only saw the obvious, the supposedly easy to handle, but by no means the complex interactions of the island(s), the sea, and the mainland. According to the Hawaiian author Sam Low (2000, para. 2), this view corroborates common continental perspectives of islands. Islanders, however, would see "the whole picture, 
foreground and background, land and ocean, as a single unified composition." While we, as foreigners from mainland Europe, only knew Malta from travel catalogues or holidays before our research, we conceived of Malta as a small island-state at the periphery of the EU.

During research we realized that perceptions of smallness varied among us and our refugee research partners. While we found Malta's smallness convenient as we did not have to cover long distances for our research, our research partners often felt isolated because they lacked travel documents which would allow them to leave Malta. How people perceive periphery, isolation, and smallness depends on the unequal distribution of mobility. Following geographer Doreen Massey's (1993) concept of "power-geometries," it is crucial to "examine not only what flows into and across space, but who controls the production, the content, and directionality of these flows" (Massey, 1994, p. 154). We observed that the ability to move and control others' mobility, as well as the unequal accessibility to different types of spaces, resulted in "differential mobility" (Sheller, 2021, p. 1442). The sea, through which most of the refugees entered Malta, represented an isolating element for them due to a lack of travel documents as land borders are usually easier to cross than sea borders without documents. For us, however, the sea was not an insurmountable hurdle. With our EU passports we could make use of the travel connections to the mainland at any time. The control of transportation corridors, both sea and air, shaped by coloniality and racial bordering (Bhimull, 2017), allowed us to come and go - thereby participating in the production of unequal "mobility regimes" (Sheller, 2021, p. 1443) — and prevented many refugees' mobility.

Acquiring physical but also social mobility in this context is difficult for certain actors. Many refugees told us that they always felt observed because of the island's smallness. This feeling was also transferred to us in a way. We were afraid that our refugee research partners, if they were seen with us, could get into trouble, and that if we were seen with refugees, we would lose access to certain bureaucrats, politicians, and other members from the highest echelons of politics and society. It was not uncommon for institutional interviewees to know about us before the interview: either by word of mouth or because our contact details had already been passed on to them in advance by people we had interviewed before. For example, one of our business cards was already stapled in the calendar of an employee of the Ministry of the Interior before the interview. That people knew about the presence of foreign researchers is also related to the small size of the island-state and the well-connected network of actors.

Against the backdrop of these dynamics and with the aim of our research consisting of neither reproducing naturalized notions of smallness nor of fuelling anti-refugee discourse, but instead of considering the intersection of smallness, islandness, and (im)mobility, we asked ourselves the following questions: what does conducting research in a place characterized by intense (geographical) proximity of different actors really mean? This is especially relevant in a context in which different research partners' interests are diametrically opposed. What happens when our paths (involuntarily) cross with various interest groups? How do we deal with the fact that political discourse uses smallness to reject refugees, while we were simultaneously connected to them? Can we, while being critical of the discourse of defense, even write about smallness, knowing that despite our solidarity with people experiencing forced migration conditions, the knowledge we produce could be beneficial to this discourse? 


\section{Empirical part: Dimensions and meanings of (un)making smallness}

Smallness, as discussed in this article, is more than just a geographical feature or a category used to classify and categorize territory. Smallness, instead, is produced and practiced, narrated and navigated, and intersects, as we argue, with islandness and policies of (im)mobility in various ways. Three modes through which smallness is produced at this intersection are particularly relevant: (1) smallness as an argument to keep refugees at bay, (2) smallness as an argument for transit, and (3) experienced smallness in the context of a lack of documents and feeling observed.

(1) Smallness as an argument for defense at sea and on the island(s)

During fieldwork, we were repeatedly told that Malta could receive no more refugees because the state was simply too small. While islands like Lampedusa or Lesbos are able to relocate refugees to mainland Italy and Greece, respectively, the Maltese authorities do not have this option. In June 2018 we visited a very popular tourist spot and talked to a young man who worked as a waiter in a bar about current migration movements. He informed us: "This country is already so full. It is overpopulated and there are already hardly any apartments left. Migration is the last thing that would do us any good." The reason for our conversation was the recent news that the Maltese government had rejected the rescue ship Aquarius a few days prior. As a result, the refugees were not allowed to land in Malta and had to remain at sea together with the rescue crew. The Maltese government refused to let them disembark, although Malta would have been the nearest safe haven. The crew ran out of food and strength to persevere, because the medical care on board was designed for shorter periods; ultimately, the Spanish government 'solved' the issue by granting permission to disembark on Spanish territory. In the last few years, there have been repeated discussions in Malta about whether refugees should be allowed to go ashore or not. A decisive factor in these discussions was the defensive attitude against refugees, which Peter, a bus driver, emphasized. He said that his friends were convinced that the island-state was already too crowded and that the EU was not helping Malta enough to prevent refugees from crossing from North Africa: "They [my friends] want to go out to sea themselves with their boats and ward off the refugees. If necessary, they will use force," Peter stated in May 2013. Especially since Malta's accession to the EU in 2004, boat migration has been perceived as a threatening and overburdening phenomenon for the local asylum system and the island-state's society. For years, the country's small size has been used as a powerful reference point to legitimize restrictive migration and asylum measures, to manage and detain refugees and to make it virtually impossible for them to stay long term.

This was expressed by the pushbacks at sea as well as by detaining, for various reasons, all new arrivals without exception until the end of 2015 (see Mainwaring \& Silverman, 2017). These efforts represented attempts to keep refugees away from the Maltese population, which were often viewed as a homogeneous, white and Christian society. With the increase in boat migration to Malta since 2002, people who experienced forced migration have been labelled as 'others' from the outset. These tendencies of change and their precarious placement on the fringes of society are also reflected in political decisions (see Klepp, 2011). Political discourse emphasized the "securitization" (Gerard \& Pickering, 2014) of the border, as well as the need 
for protection against "dangerous/unwanted intruders" (Pisani, 2013, p. 78). In 2009, the former Minister of Interior (quoted in Calleja, 2009) announced:

Given Malta's size you cannot expect the government to release illegal immigrants into the streets, especially in light of increasing numbers. This would send the wrong message and spell disaster for the country [...]. As a minister I am responsible, first and foremost, for the protection of Maltese citizens.

Maltese society was understood as worthy of protection and, decisively, those who reached Malta to seek protection were not. To imprison all new arrivals is an extreme way of keeping refugees at a distance. Yet, there was no integration law that refugees could invoke until 2017. An integration policy was perceived as unnecessary primarily because locals believed refugees wanted to migrate to larger EU countries such as Germany or Sweden instead of remaining in Malta. However, further travel is made difficult due to the Dublin Regulation that was adopted in 2003 and determined that the EU member state in which refugees first entered the EU was responsible for examining their asylum application. Alice Zammit, who also worked for LMAO, stated the following (interview in February 2015):

You know, it's very obvious. And I think the more we are making people stay by Dublin II [authors' note: at the time of the interview, Dublin III already existed] or by integration, the more we are doing harm to these people. [...] You know, we are trying to help but yet again nobody wants our help. So it's useless telling us emphasize on integration.

As a consequence, integration was considered "harmful" for refugees. With the adoption of the Integration Policy at the end of 2017, however, these attitudes did not disappear. Although there was no integration law for a long time and refugees were understood as nonpermanent islanders, newcomers were still expected to "integrate" into society (see Nimführ et al., 2020). A certain (ascribed) responsibility to initiate integration was something we repeatedly noticed, especially in discussions with institutional actors. The majority of refugee interlocutors reported that care workers told them to stop going to the mosque and to do away with their Muslim faith. Instead, they were instructed to receive an education and learn both English and Maltese. They were also supposed to have graduation diplomas, as one accommodation manager summarized in April 2013: "They should integrate themselves and start a new life." Yet, what was understood here as a place of "new" life? Reports in the daily newspaper Malta Today show that the "new" life did not include Malta, as revealed by the headline, "152 refugees leave Malta to start new life in Germany" (Dalli, 2011). Reports about the departure of refugees from Malta in the form of regulated relocation programs, for example, referred to the "old' life as pertaining to the African continent while the "new" life focused on the (large) European mainland. In discussions, Malta's reception capacities were compared with the EU mainland. This was explained by a director of the detention center in an interview in April 2016:

Now, being a small place, small country, like Malta, a couple of thousand means a lot, because in comparison to the size of the country and the number of people living 
here, 13,000 is a lot. $1,000,000$ in Italy is not a lot, considering the population. 3,000,000 in the whole of Europe isn't a lot, even 6,000,000 is not a lot.

The interviewee claimed to be in a position to determine how many refugees would be unproblematic in other countries. In both our interviews as well as in public discourse, it was repeatedly emphasized that Malta's lack of a mainland was a decisive factor for not being able to host refugees long-term. In the summer of 2020, externalization mechanisms manifested themselves for the first time outside the Maltese islands regarding forced migration: during the COVID-19 pandemic, the government had chartered leisure boats and housed refugees off the coast. While this was discussed as a public health measure - i.e., refugees would otherwise spread the virus - Baldacchino (2020) concluded that if there were no islands, they would have to be invented, because even island-states would 'need' their islands to move the unwanted offshore. Although this new practice has not yet been institutionalized, these considerations and the desire to refuse access to Malta and instead accommodate refugees 'offshore' are not new. Since Malta, in contrast to larger states in terms of both area and population, does not necessarily have the capacity to receive and house refugees long-term, the island-state in the Mediterranean is seen as a stopover; a transit country along the journey from Africa to Europe.

\section{(2) Smallness as an argument for transit}

This constructed stopover was also defined as a "bus stop" by LMAO employee Alice Zammit (interview in February 2015): "We are like a bus stop. The majority, and this is true, the majority were leaving Malta. And the majority wanted to go to America or to France or to Sweden." The fact that refugees would not want to stay in Malta also relates to the comparatively small space, and that Malta is an island-state. "They won't find what they were looking for here. This is not what they imagined Europe to be. Just being on an island is not what they wanted," noted Nina Cortis from the Ministry of Family Affairs in July 2015, who was convinced that most refugees wanted to leave the island-state. We noticed that refugees were often ascribed dissatisfaction with Malta - they either found it too small or had different expectations of Europe; thus, they were viewed to be in a permanent state of transit.

Many refugee research partners themselves also repeatedly addressed their desire to leave Malta. Yet, we perceived different patterns of explanation for this, which were not necessarily related to smallness. Unlike local actors, they justified their transit and the "bus stop phenomenon" by noting that they did not feel welcome in Malta: "The people here do not want us to be successful. They want us to remain stupid," was Bilal's perception in July 2015. He grew up in Somalia, arrived in Malta in the fall of 2012 and was thereafter classified as an unaccompanied minor. Others wanted to move closer to their families in other EU countries, which was only possible if they had a corresponding legal status. The Gambian Ebrima, for example, whose asylum application had been rejected in Malta, pointed to a family photo and said that he had not seen his uncle for a long time, although he lived relatively close by in Spain: "It's all about the papers. I cannot even travel from here to Spain to visit my uncle. I have no one here" (interview in July 2015). He arrived by boat in 2013 and was detained for more than a year due to irregular entry. Even thereafter, Ebrima spent a long time trying to settle in Malta and gain a foothold. First, he worked as a mechanic for one of Malta's largest harbor tour operators. Then he began to train as a seaman at his own expense, which he had 
to stop due to a lack of financial resources. After four unsuccessful years, he decided to leave Malta without papers. "Malta is nice. I really like Malta and would like to stay here. But living in Malta without documents is like walking in a roundabout all the time," he stated in July 2015. Smallness in Ebrima's account relates to the equation of smallness and a feeling of imprisonment; he interpreted Malta as a roundabout because he lacked proper documents to get access to social services or to leave the island-state. His desire to leave Malta was based on a lack of future prospects and family ties and did not concern geographical smallness in the first place.

\section{(3) Smallness, lack of travel documents, and feeling observed}

While Ebrima and Filad were not bothered by Malta's geographical smallness, we also met other refugees who constantly mentioned Malta's geographical smallness and its limited space. Buba, who arrived in Malta with the same boat as Ebrima and whose asylum application was also rejected, similarly associated Malta's smallness with an 'open-air prison': "To be in Malta is like being in prison. You stay stuck on the island," the Sierra-Leonean explained in May 2018 after he had left Malta for Italy independently and who now lives as a regularized citizen in the Netherlands. For some of our refugee research partners, this feeling of permanent imprisonment stems from the fact that Malta is an island-state and, unlike other islands such as Lampedusa, has no mainland. In addition, the majority of our refugee research partners lacked the necessary travel documents to travel to the EU mainland in a regulated fashion. "If you want to leave Malta, you must always take a plane or a ship. And for that we need papers. If you don't have them, you can't even board an aircraft," Bilal, a young Somali, said in July 2015. Tayeb, who is a father of four children and who had been living in Malta for more than ten years without a residence status, also expressed this frustration regarding the lack of freedom of movement: "When the weather is good, you can sometimes even see Italy. And I can't even travel to Italy from here." Some refugees perceived the fact that Malta is surrounded by water as a mobility disadvantage. "Those who arrive in Italy at least have a chance to try to cross the border undetected," said Blaze in the spring of 2016. He came to Malta from Nigeria together with his wife in March 2011. After five years of undocumented residence in Malta, they saw no possibility for themselves and their two children - who had been born in Malta - to ever leave the island-state in an unregulated or regulated manner. The materialized physical isolation of Malta made some of our refugee research partners feel trapped. "In Malta, I feel like I am permanently in a tunnel where there is no light at the end," the young Somali Absimil reported in June 2013.

While some felt Malta was well connected, others felt isolated. Abdul's perspective on the island-state was perhaps the most radical we heard. The young man from Somalia, who successfully left the island-state for the United States of America with a resettlement program in 2017, described Malta as a "shitty stone in the water." He said this while reflecting on the African continent, in particular his description of South Africa, where he lived for a while before coming to Malta. "You know, South Africa is a big country. There are reasonable roads, many universities, many people from many countries. And in Malta they want to tell me that they know and have everything? It doesn't make sense to me," Abdul explained in July 2013.

The majority of refugees whose asylum decision was rejected felt that they were confined in Malta. People affected by rejected asylum decisions were stuck for years - both 
geographically and in terms of fulfilling their personal goals. They were unable to organize travel to their countries of origin, because they were either threatened with violence upon their return or lacked travel documents, and the Dublin Regulations also prevented them from reapplying for asylum in another EU country. Only in exceptional cases were they allowed to travel to other EU countries and stay there for three months before returning to the island-state. Even though this feeling of confinement primarily related to the absence of a protection status and the lack of documents, refugee research partners also told us that Malta's small size reinforced this feeling. "When I first arrived here, I knew nothing. But that was three years ago now. I looked at this place like a tourist, I looked at everything. But after a short time, you know everything. There's not so much here. It gets boring then," stated Absimil, who still lives in Malta, in April 2016.

In addition to feeling confined, the majority of our refugee research partners also felt constantly monitored: for them, being in Malta was like being in a panopticon (Foucault, 1993). Deeqo talked intensively and vividly about these dynamics. He was housed in a home for young people classified as UAMs. One rule of the home was that the minors had to sign in and out: when signing out, the staff asked where the residents were going, and their answer was noted in a report book. At shift changes, all details were discussed among staff. One day, Deeqo indicated that he was going to Balbi, where he wanted to meet friends to watch football. However, on his way to Balbi, he received a call from a friend from Kittieba and went there instead. In Kittieba, he met a care worker from the home, who then checked the report book during her next shift and found that he had indicated that he was going to Balbi. Deeqo was confronted with this incident and had to justify his spontaneous route change, as he reported in May 2013: "They see you everywhere and in everything you do. You can't go underground here," was the lesson he learned. As a consequence of such experiences, many had the feeling that they could not move freely. Statements like those made by Joseph, who worked in a hotel in a city popular with tourists, unsettled us further. After we remarked that there were relatively few cameras in public spaces compared to other countries, he told us in June 2018: "In Malta we don't need cameras. Why not? Because here 400,000 pairs of eyes always see everything. Everyone knows everyone. So why cameras?" Even though cameras are largely absent from public spaces, our research partners from sub-Saharan Africa were those mainly being controlled by institutional actors. The actual knowledge about this documentation of their behavior, as well as informal observations, led to changes in their practices. Ebrima wanted to take pictures of the Balbi Open Center for our research, as we were not granted access to the compound. Ebrima felt it was important to show what it looked like inside. His idea of taking photos for us never materialized, however: "I was too worried, because we are not allowed to take photos. There are so many cameras in Balbi, I didn't want to risk it. I am sorry," he apologized in July 2015.

\section{Analytical remarks and conclusion: Whither smallness?}

In this article, we asked how island-related smallness is produced and situationally used in the context of refugee arrival in Malta. We examined: how is island-related smallness produced and used situationally in the context of (im)mobility? How do smallness, islandness, and (im)mobilizing policies intersect at the EU's external border on the Maltese island-state? In doing so, this article has added both empirical findings and conceptual thinking to strands of 
research that encourage deconstructing smallness and thinking of it as a relational concept in order not to reproduce an oversimplified discourse on geographical smallness. Ethnographic studies in particular have the strength to sense the various - everyday and discursive (meaning-)makings of spatial scales, at the same time reflecting on the researchers' entanglements with these categories and using them in an analytical fashion.

The empirical material demonstrates that smallness indeed was a dominant category and topic among actors on the ground and during fieldwork. Yet, perspectives on and experiences with smallness vary among different actors and are inextricably linked with their legal and social position in society. In addition, how and if smallness is felt and experienced often relates to one's own (in)ability to move. Furthermore, the empirical material illustrates that different actors gave space different meanings and produced smallness in various ways (Brand, 2008, p. 173). Institutional actors mainly used smallness as an argument to keep refugees at bay and as an argument for transit after their arrival. Employees of the institutional border regime benefit from the island-state's small size in the form of short communication channels to other institutions. At the same time, a large number of NGOs in a small area resulted in differentiation and competitive dynamics. The raison d'être of individual NGOs was negotiated: Who does what when there is already a large support system in a geographically small area? While intense proximity facilitated the exchange of knowledge even among refugees, their movements were also easier to track due to the island-state's small size: it was hardly possible to disappear into an anonymous mass. In addition, refugees often felt as if they were under surveillance when they left the open center, as they encountered staff outside the centers who reported back to their colleagues whom they had met and where. Malta's small size simultaneously promoted and eroded cohesion among people.

The majority of our refugee research partners perceived Malta as an 'open-air prison' and felt permanently monitored due to the proximity of different actors and short communication channels. Nevertheless, it was not just about smallness as a geographical fact of Malta. Social factors, such as being watched, played an important role here, but it was above all regulations and the EU border regime that materialized smallness for refugees. They could not travel regularly, but instead had to stay in Malta or leave the island-state independently. Changes in policy, such as the switch to Dublin III, however, not only changed a person's actual legal status and possibilities to travel, but also the attitude towards Malta and its smallness. Feelings of being imprisoned or of interpreting Malta solely as small may be augmented because regulations change. This was also demonstrated by refugees we met and who were legally allowed to settle elsewhere in the EU: while they had complained about Malta's smallness when they were still living on the islands, they developed a different perspective when they returned to the island-state as tourists to visit their friends.

This article has further demonstrated against the backdrop of ethnographic material and a theoretical perspective embedded in both Island Studies and social constructivist understandings of space that smallness becomes effective and experienced at the intersection of islandness and (im)mobility policies. The material illustrated who produces smallness, how, and from what position. While it cannot be denied that the geographical smallness of the Maltese archipelago makes it easier for various actors to implement the policies of (im)mobility, it was also the neighborhood-is-watching-you-atmosphere which contributes to the production and materialization of smallness. The fact that Malta only has a maritime border and no mainland was only one reason why the island-state sometimes felt small in the 
view of refugees; that they were not allowed to travel was clearly more substantial here and intensified geographic smallness. Having derived smallness from the ethnographic material instead of applying the category deductively — and having offered a multi-actor perspective on meaning-making and producing smallness - helped challenge "Western ways of knowing and expressing knowledge" (Grydehøj, 2018, p. 7). Thus, it is fair to say that smallness is not only more than a geographical feature, but that looking at smallness at the intersection of islandness and policies helps to understand geographical features in differentiated fashions to address oversimplifications of smallness. This is important both to correspond to decolonial approaches in Island Studies which seek to move beyond viewing islanders as simple, unconnected, and dominated by others, and to not further fuel anti-immigrant discourse in Malta and beyond. Smallness, as we have shown, is context-specific and should not be understood as the only category of analysis, but is interwoven with other discourses. In Malta, this is particularly evident with discourses surrounding overtourism and a contested housing market, notions of a homogenous society, health policies, and especially debates about the role of EU institutions in relation to local authorities and ministries, as the arrival of refugees is not only about migration to Malta, but to the EU on the whole.

Against the backdrop of ethnographic material, we understand smallness as produced in narratives, as emergent in practices, and as materialized in both geographical features and policies. We suggest defining smallness on the basis of (1) the size of the population and/or research site, (2) the processes of attribution, and (3) the processes of perception and performing a specific space. With our reflections and connections from empirical research, methods, and theories, we seek to stimulate a debate that moves beyond the fixed and excluding discourse of smallness. To this end, it is important for us to understand smallness as complex and multifaceted. Carving out practices of doing smallness and different perspectives on smallness are necessary in Island Studies to avoid "missing the forest for the trees, the archipelago for the islands" (Grydehøj, 2017, p. 8).

Yet, there are a few caveats to be mentioned here. We only provided a small sample, and our analysis of how smallness intersects with policies and islandness makes no claim concerning completeness, as negotiations around smallness are dynamic and always in process. In addition, as researchers from the Global North - despite our efforts to deconstruct reductive conceptions and to "rethinking/retheorizing from alterity" (Naylor et al., 2018, p. 200) - we always speak from a particular perspective, as “"knowledge' is geopolitical, always connected to people, power, and place” (Grydehøj et al., 2021, p. 4). Still, we are convinced that thinking with and against smallness is fruitful for both Island and Migration Studies and their various intersections in order to reveal ascription and disempowerment processes.

\section{Acknowledgements}

We are incredibly grateful to the refugees who shared their stories with us, and also thank the institutional actors for taking time to participate in our studies. Our sincere appreciation for feedback and encouragement goes to Adam Grydehøj and Jonathan Pugh. We also wish to thank three anonymous reviewers whose valuable feedback and constructive ideas significantly improved this paper. Thanks to Mark McAdam for editing. 


\section{References}

Anckar, D. (2006). Islandness or smallness? A comparative look at political institutions in small island states. Island Studies Journal, 1(1), 43-54.

Baldacchino, G. (2020, June 24). Migration policy at sea in 2020: Malta and its four temporary islands in the Mediterranean [Conference presentation]. ISISA Global Island Studies Webinar 2020.

Baldacchino, G. (2018). Preface. In G. Baldacchino (Ed.), The Routledge international handbook of island studies (pp. xix-xxxv). Routledge. https://doi.org/10.4324/9781315556642

Baldacchino, G. (2014). Islands and the offshoring possibilities and strategies of contemporary states: Insights on/for the migration phenomenon on Europe's southern flank. Island Studies Journal, 9(1), 57-68.

Baldacchino, G. (2010). "Upside down decolonization" in subnational island jurisdictions: Questioning the "post" in postcolonialism. Space and Culture, 13(2), 188-202. https://doi.org/10.1177/1206331209360865

Baldacchino, G. (2008). Studying islands: On whose terms? Some epistemological and methodological challenges to the pursuit of island studies. Island Studies Journal, 3(1), $37-56$.

Baldacchino, G. (2007). Introducing a World of Islands. In G. Baldacchino (Ed.), A world of islands: An island studies reader (pp. 1-29). Institute of Island Studies \& Agenda Academic.

Baldacchino, G. (2005). Editorial: Islands: Objects of representation. Geografiska Annaler. Series B, Human Geography, 87(4), 247-251. https://doi.org/10.1111/j.04353684.2005.00196.x

Baldacchino, G. (2004). The coming of age of island studies. Tijdschrift voor Economische en Sociale Geografie, 95(3), 272-283. https://doi.org/10.1111/j.1467-9663.2004.00307.x

Banivanua Mar, T. (2016). Decolonisation and the Pacific. Indigenous globalization and the ends of Empire. University Press. https://doi.org/10.1017/cbo9781139794688

Belina, B. (2008). Skalare Praxis. In M. Wissen, B. Röttger, \& S. Heeg (Eds.), Politics of scale. Räume der Globalisierung und Perspektiven emanzipatorischer Arbeit (pp. 106-123). Westfälisches Dampfboot.

Bernardie-Tahir, N., \& Schmoll, C. (2014). Islands and the undesirables: Irregular migration to Southern European Islands. Journal of Immigrant and Refugee Studies, 12(2), 87-102. https://doi.org/10.1080/15562948.2014.899657

Bhimull, C. (2017). Empire in the air: Airline travel and the African diaspora. NYU Press. Brand, U. (2008). Multiskalare Hegemonie. Zum Verhältnis von Führung, Herrschaft und Staat. In M. Wissen, B. Röttger, \& S. Heeg (Eds.), Politics of scale. Räume der Globalisierung und Perspektiven emanzipatorischer Arbeit (pp. 169-185). WestfälischesDampfboot.

Broodbank, C. (2000). An island archaeology of the early Cyclades. Cambridge University Press.

Calleja, C. (2009, April 18). Doing away with detention would spell disaster. Times of Malta. http://www.timesofmalta.com/articles/view/20090418/local/doing-away-withdetention-would-spell-disaster.253274

Chandler, D., \& Pugh, J. (2020). Islands of relationality and resilience: The shifting stakes of the Anthropocene. Area, 52(1), 66-72. https://doi.org/10.1111/area.12459 
Dalli, M. (2011, November 29). 152 refugees leave Malta to start new life in Germany. Malta Today. https://www.maltatoday.com.mt/news/national/14133/152-refugees-leavemalta-to-start-new-life-in-germany

De Genova, N. (2015, May 20). The border spectacle of migrant "victimization". openDemocracy. $\quad$ https://www.opendemocracy.net/beyondslavery/nicholas-degenova/border-spectacle-of-migrant-\%E2\%80\%98victimisation\%E2\%80\%99

Dracklé, D. (2015). Ethnographische Medienanalyse: Vom Chaos zum Text. In C. Bender \& M. Zillinger (Eds.), Handbuch der Medienethnographie (pp. 387-404). Reimer. https://doi.org/10.5771/9783496030065-387

Eckert, A., Schmidt-Lauber, B., \& Wolfmayr, G. (Eds.). (2020). Aushandlungen städtischer Größe. Mittelstadt leben, erzählen, vermarkten. Böhlau Verlag. https://doi.org/10.7767/9783205232049

Foucault, M. (1993). Überwachen und Strafen. Die Geburt des Gefängnisses. Suhrkamp.

Franck, A. K. (2017). Im/Mobility and deportability in transit: Lesvos island, Greece, June 2015. Tijdschrift voor Economische en Sociale Geografie, 108(6), 879-884. https://doi.org/10.1111/tesg. 12285

Gerard, A., \& Pickering, S. (2014). Gender, securitization and transit: Refugee women and the journey to the EU. Journal of Refugee Studies, 27(3), 338-359. https://doi.org/10.1093/jrs/fet019

Gingrich, A., \& Hannerz, U. (2017). Introduction: Exploring small countries. In U. Hannerz \& A. Gingrich (Eds.), Small countries. Structures and sensibilities (pp. 1-44). University of Pennsylvania Press. https://doi.org/10.9783/9780812293791

Gottschalk, A., Kersten, S., \& Krämer, F. (Eds.). (2018). Doing space while doing gender. Vernetzungen von Raum und Geschlecht in Forschung und Politik. transcript. https://doi.org/10.14361/9783839435366

Grydehøj, A. (2018). Hearing voices: Colonialism, outsider perspectives, island and Indigenous issues, and publishing ethics. Island Studies Journal, 13(1), 3-12. https://doi.org/10.24043/isj.54

Grydehøj, A. (2017). A future of island studies. Island Studies Journal, 12(1), 3-16.

Grydehøj, A., Bevacqua, M. L., Chibana, M., Nadarajah, Y., Simonsen, A., Su, P., Wright, R., \& Davis, S. (2021). Practicing decolonial political geography: Island perspectives on neocolonialism and the China threat discourse. Political Geography, 85, 102330. https://doi.org/10.1016/j.polgeo.2020.102330

Hau'ofa, E. (1994). Our sea of islands. The Contemporary Pacific, 6(1), 147-161.

Hess, A. L. (1986). Overview: Sustainable development and environmental management of small islands. In W. Beller, P. d'Ayala, \& P. Hein (Eds.), Sustainable development and environmental management of small islands (Man and biosphere series, vol. 5). UNESCO.

Hörning, K. H., \& Reuter, J. (Eds.). (2004). Doing culture: Neue Positionen zum Verhältnis von Kultur und sozialer Praxis. transcript. https://doi.org/10.14361/9783839402436

Kelman, I. (2021). Pandemic and post-pandemic islandness. Building and wrecking resilience. In J. E. Randall (Ed.), Island Economic Cooperation Forum. Annual report on global islands 2020 (pp. 105-126). Island Studies Press \& Foreign Affairs Office of Hainan Province. https://projects.upei.ca/unescochair/files/2021/04/Annual-Report-on-GlobalIslands-2020-Chapter-4-Pandemic-and-postpandemic-islandness-Ilan-Kelman.pdf 
Kelman, I. (2018). Islandness within climate change narratives of small island developing states (SIDS). Island Studies Journal, 13(1), 149-166. https://doi.org/10.24043/isj.52

King, R. (2009). Geography, islands and migration in an era of global mobility. Island Studies Journal, 4(1), 53-84.

Klepp, S. (2011). Europa zwischen Grenzkontrolle und Flüchtlingsschutz. Eine Ethnographie der Seegrenze auf dem Mittelmeer. transcript.

https://doi.org/10.14361/transcript.9783839417225

Lefebvre, H. (1998). The production of space. Blackwell.

Lewis, J. (2009). An island characteristic. Shima, 3(1), 3-15.

Löw, M. (2001). Raumsoziologie. Suhrkamp.

Low, S. (2000). A sea of islands. Hawaiian voyaging traditions. http://archive.hokulea.com/ike/moolelo/sea of islands low.html

Lowenthal, D. (1992). Small tropical islands: A general overview. In H. M. Hintjens \& M. D. D. Newitt (Eds.), The political economy of small tropical islands (pp. 19-29). University of Exeter Press.

Mainwaring, $\dot{\mathrm{C}}$. (2019). At Europe's edge. Migration and crisis in the Mediterranean. University Press.

Mainwaring, C., \& Silverman, S. J. (2017). Detention-as-spectacle. International Political Sociology, 11(1), 21-38. http://doi.org/10.1093/ips/olw016

Mannik, L. (Ed.). (2016). Migration by boat. Discourses of trauma, exclusion, and survival. Berghahn. https://doi.org/10.2307/j.ctvpj7hqz

Massey, D. (1994). Space, place and gender. University of Minnesota Press.

Massey, D. (1993). Power-geometry and a progressive sense of place. In J. Bird, B. Curtis, T. Putnam, G. Robertson, \& L. Tickner (Eds.), Mapping the futures: Local cultures, global change (pp. 55-69). Routledge. https://doi.org/10.4324/9780203977781

Nadarajah, Y. (2007). The outsider within: Commencing fieldwork in the Kuala Lumpur/Petaling Jaya corridor, Malaysia. International Journal of Asia-Pacific Studies, 3(2), 109-132.

Nadarajah, Y., \& Grydehøj, A. (2016). Island studies as a decolonial project. Island Studies Journal, 11(2), 437-446.

Naylor, L., Daigle, M., Zaragocin, S., Ramfrez, M., \& Gilmartin, M. (2018). Interventions: Bringing the decolonial to political geography. Political Geography, 66, 199-209. https://doi.org/10.1016/j.polgeo.2017.11.002

Nimfuihr, S., \& Otto, L. (2020). Doing research on, with and about the island: Reflections on islandscape. Island Studies Journal, 15(1), 185-204. https://doi.org/10.24043/isj.107

Nimführ, S., Otto, L., \& Samateh, G. (2020). Denying, while demanding integration: An analysis of the integration paradox in Malta and refugees' coping strategies. In S. Hinger \& R. Schweitzer (Eds.), Politics of (Dis)Integration (pp. 161-181). Springer. https://doi.org/10.1007/978-3-030-25089-8 9

Otto, L., \& Nimführ, S., \& Bieler, P. (2019). Preserving Maltese identity in refugee management. On the emergence and absence of a prison spatiality. Shima, 13(2), 135154. https://doi.org/10.21463/shima.13.2.11 
Pisani, M. (2013). "We are going to fix your vagina, just the way we like it." Some reflections on the construction of (Sub-Saharan) African female asylum seekers in Malta and their efforts to speak back. Postcolonial Directions in Education, 2(1), 68-99.

Pugh, J. (2018). Relationality and island studies in the Anthropocene. Island Studies Journal, 13(2), 93-110. https://doi.org/10.24043/isj.48

Pugh, J. (2016). The relational turn in island geographies: Bringing together island, sea and ship relations and the case of Landship. Social \& Cultural Geography, 17(8), 1040-1059. https://doi.org/10.1080/14649365.2016.1147064

Royle, S. A (2010). Postcolonial culture on dependent islands. Space and Culture, 13(2), 203215. https://doi.org/10.1177/1206331209358230

Royle, S. A. (2001). A geography of islands: Small island insularity. Routledge.

Royle, S. A., \& Brinklow, L. (2018). Definitions and typologies. In G. Baldacchino (Ed.), The Routledge international handbook of island studies (pp. 3-20). Routledge. https://doi.org/10.4324/9781315556642-1

Schroeder, J. (2003). Der Flüchtlingsraum als ein „totaler Raum“: Bildungsinstitutionen und ihre Grenzen. In U. Neumann, H. Niedrig, J. Schroeder, \& L. Seukwa (Eds.), Lernen am Rande der Gesellschaft. Bildungsinstitutionen im Spiegel von Flüchtlingsbiografien (pp. 379397). Waxmann.

Sheller, M. (2021). Restructuring tourism in the Caribbean: Connecting pandemic recovery, climate resilience and sustainable tourism through mobility justice. Journal of Sustainable Tourism, 29(9), 1436-1449. https://doi.org/10.1080/09669582.2020.1791141

Sheller, M. (2009). Infrastructures of the imagined island: Software, mobilities, and the architecture of Caribbean paradise. Environment and Planning A: Economy and Space, 41(6), 1386-1403. https://doi.org/10.4324/9780203417942

Stratford, E., Baldacchino, G., McMahon, E., Farbotko, C., \& Harwood, A. (2011). Envisioning the archipelago. Island Studies Journal, 6(2), 113-130.

Telesford, J. N. (2021). Critiquing 'islandness' as immunity to COVID-19: A case exploration of the Grenada, Carriacou and Petite Martinique archipelago in the Caribbean region. Island Studies Journal, 16(1), 308-324. https://doi.org/10.24043/isj.155

Triandafyllidou, A. (2014). Multi-levelling and externalizing migration and asylum: Lessons from the southern European islands. Island Studies Journal, 9(1), 7-22.

Veenendaal, W., \& Corbett, J. (2020). Clientelism and small states: How smallness influences patron-client networks in the Caribbean and the Pacific. Democratization, 27(1), 61-80. https://doi.org/10.1080/13510347.2019.1631806

Vogiatzakis, I. N., Zomeni, M., \& Mannion, A. M. (2017). Characterizing islandscapes: Conceptual and methodological challenges exemplified in the Mediterranean. Land, 6(14), 1-13. https://doi.org/10.3390/land6010014

Walshe, R. A., \& Stancioff, C. E. (2018). Small island perspectives on climate change. Island Studies Journal, 13(1), 13-24. https://doi.org/10.24043/isj.56

Welz, G. (2013). Die Pragmatik ethnographischer Temporalisierung. Neue Formen der Zeitorganisation in der Feldforschung. In S. Hess, J. Moser, \& M. Schwertl (Eds.), Europäisch-ethnologisch Forschen. Neue Methoden und Konzepte (pp. 39-54). Reimer. 